慶應義塾大学学術情報リポジトリ

Keio Associated Repository of Academic resouces

\begin{tabular}{|c|l|}
\hline Title & $\begin{array}{l}\text { Free Radical Scavenger, Edaravone, Attenuates Steatosis and Cell Death via Reducing } \\
\text { Inflammatory Cytokine Production in Rat Acute Liver Injury. }\end{array}$ \\
\hline Sub Title & $\begin{array}{l}\text { 新規ラジカル消去剤エダラボンは炎症性サイトカインの抑制を介してラット急性肝障害における } \\
\text { 脂肪化、細胞死を抑制する }\end{array}$ \\
\hline Author & 中本, 伸宏(Nakamoto, Nobuhiro) \\
\hline Publisher & 慶應医学会 \\
\hline Publication year & 2004 \\
\hline Jtitle & 慶應医学 (Journal of the Keio Medical Society). Vol.81, No.2 (2004.6),p.17- \\
\hline JaLC DOI & \\
\hline Abstract & \\
\hline Notes & 号外 \\
\hline Genre & Journal Article \\
\hline URL & https://koara.lib.keio.ac.jp/xoonips/modules/xoonips/detail.php?koara_id=AN00069296-2004060 \\
& 2-0017 \\
\hline
\end{tabular}

慶應義塾大学学術情報リポジトリ(KOARA)に掲載されているコンテンツの著作権は、それぞれの著作者、学会または出版社/発行者に帰属し、その権利は著作権法によって 保護されています。引用にあたっては、著作権法を遵守してご利用ください。

The copyrights of content available on the KeiO Associated Repository of Academic resources (KOARA) belong to the respective authors, academic societies, or publishers/issuers, and these rights are protected by the Japanese Copyright Act. When quoting the content, please follow the Japanese copyright act. 


\title{
A Free Radical Scavenger, Edaravone, Attenuates Steatosis and Cell Death via Re- ducing Inflammatory Cytokine Production in Rat Acute Liver Injury.
}

\author{
（新規ラジカル消去剤エダラボンは炎症性サイトカインの抑制を介して \\ ラット急性肝障害における脂肪化、細胞死を抑制する)
}

中 本 伸宏

\section{内容の要旨}

【緒言】種々の肝障害において、フリーラジカル、炎症性サイトカ インが重要な役割を果たしている。エダラボンは新規に開発された ラジカル消去剤であり、脳血管障害においてその有効性が知られて いる。しかし本薬の肝障害における効果および作用機序については 解明されていない。そこで申請者はその点を明らかにする目的で、 ラット四塩化炭素 (carbon tetrachloride ; 以下 $\mathrm{CCI}_{4}$ ) 急性肝障害モデ ルを用いて検討を行った。

【材料・方法】実験にはWistar系雄性ratを用いた。オリーブオイル を腹腔内投与するコントロール群、 $\mathrm{CCI}_{4}$ を腹腔内投与する群、 $\mathrm{CCI}_{4}$ 投与直後、 3 時間後にエダラボンを静脈内投与する群の計 3 群を作 成した。血清生化学的検討として total bilirubin（以下TB）、alanine aminotransferase (以下ALT) 、 lactate dehydrogenase (以下LDH) 值を 測定した。組織学的検討としてHE染色、oil red O染色を行い、アポ トーシスの検出としてTUNEL染色を施行した。脂質過酸化の評価と $し て$ 肝組織中の malondialdehyde (以下 MDA) の定量、4hydroxynonenal (以下4-HNE) 免疫組織染色を、DNA酸化傷害の評価 として8-hydroxy-2-deoxyguanosine（以下8-OHdG）免疫組織染色を 行った。また炎症性サイトカインの評価として、ELISA法による血, 清中 TNF- $\alpha$ ， IL-6, IL-10量、RT-PCR法による肝組織内 TNF- $\alpha$, IL4, IL-6， IL-10mRNAの発現を検討した。

【結果】 $\mathrm{CCL}_{4}$ 投与後に認められた血清TB, ALT, LDHの上昇はエダ ラボンの投与により有意に抑制された。 $\mathrm{CCl}_{4}$ 単独群では24時間後に 中心静脈周囲に脂肪滴の沈着、中程度の壊死性変化を認めたが、エ ダラボン投与群では障害の程度は軽度であった。また単独群で 24 , 48時間後に認められたTUNEL陽性細胞もエダラボン投与により有意 に減少した。脂質過酸化の指標は肝組織MDA定量、4-HNE免疫染色 陽性細胞数いずれも、単独群に比べエダラボン投与群で軽度であっ た。一方8-OHdGは、単独群で48時間後に核染色される肝細胞が認め られ、エダラボン投与群ではその数は有意に減少した。血清IL-6, TNF- $\alpha, I L-10$ はCCL 4 投与後それぞれ $6 ， 12 ， 24$ 時間後をピークに上 昇しエダラボンの投与により有意に低下した。また $\mathrm{CCI}_{4}$ 投与により 24時間後の肝組織中TNF- $\alpha, \mathbb{L}-4, \mathbb{L}-6, \mathrm{~L}-10 \mathrm{mRNA}$ の発現が方進 し、エダラボン併用群では有意に抑制された。

【結論】エダラボンはラジカル消去効果に加えて、その過程におい て炎症性サイトカインの産生やDNA酸化傷害を抑制することにより 急性肝障害保護効果を有することが明らかとなった。

\section{論文審査の要旨}

種々の肝障害の進展にフリーラジカルや酸化ストレスが関与する ことが知られており、ラジカルや過酸化脂質の産生抑制が肝疾患の 治療において重要である。現在までに様々な抗酸化物質による肝障 害抑制効果が報告されているが、臨床的に有用な薬物は少ない。近 年脳梗塞の治療にフリーラジカル消去剤であるエダラボンの有効性 が報告され、臨床の場において広く使われている。本研究では、エ ダラボンを将来的に臨床応用することを目的とし、ラット四塩化炭 素 (carbon tetrachloride; 以下 $\mathrm{CCl}_{4}$ ) 急性肝障害モデルを用いその肝 障害に対する効果、機序を脂質過酸化、DNA酸化傷害、炎症性サイ トカインならびに組織学的側面から検討した。その結果、 $\mathrm{CCl}_{4}$ 投与 後に認められた血清学的、組織学的変化はエダラボンの投与により 著明に改善した。その機序としてラジカル消去効果に加えて、TNF$\alpha$ ，IL-6などの炎症性サイトカインの産生やDNA酸化傷害の抑制が明 らかとなり、本薬物の今後の薬物性肝障害、肝硬変、肝癌などへの 臨床応用が期待される。

審査では、まず本実験で用いた $\mathrm{CCl}_{4}$ の投与量について質問があ り、急性肝障害をもたらす一般的な量であり、肝硬変モデルで用い る量よりは高用量であるとの説明がなされた。次に炎症性細胞浸潤 を伴う壊死性変化と脂肪変性を認める細胞のdistributionの違いの意味 について質問がなされ、部位により障害程度に違いがあり、脂肪変 性を認める細胞とnecrosis, apoptosisを認める細胞は違う可能性が高 い旨説明がなされた。また $\mathrm{CCl}_{4}$ 急性肝障害におけるラジカル、炎症 性サイトカイン、DNA酸化傷害などの各因子の相互関連について質 問がなされた。これに対し、肝細胞内に存在するCYP2E1により発生 したラジカルにより各細胞器官の脂質過酸化、DNA酸化傷害などに よる一次的な細胞障害が生じ、さらにこれらの炎症により炎症性細 胞が誘導され、炎症性サイトカインなどによる二次的な障害がもた らされる旨説明がなされた。次にビタミンE, superoxide dismutase （SOD）などの抗酸化物質による効果と本薬物の比較、今後の臨床 応用について質問がなされ、静脈投与による迅速な組織移行性、強 力な脂質過酸化抑制効果を有しており、今後薬物性、アルコール性 などの急性肝障害、劇症肝炎に対し臨床応用が期待されるとの回答 がなされた。最後に本研究の問題点として、 $\mathrm{CCl}_{4}$ 急性肝障害におけ る炎症細胞の活性化ならびに炎症性サイトカインの発現機序、エダ ラボンのP450などの薬物代謝酵素に対する影響についてのさらなる 検討が必要である旨助言がなされた。

以上のように本研究はいくつかの検討課題は残しているものの、 ラジカル抑制を介した肝障害に対する有効な治療法を確立するため の重要な研究であり、臨床的にも洒值ある研究と評価された。

論文審查担当者 主查 内科学 石井 裕正 医化学 末松 誠 病理学 岡田 保典 外科学 北島 政樹

学力確認担当者 : 審查委員長 : 末松 誠 